\title{
A Single Missense Mutation in Codon 918 of the RET Proto-Oncogene in Sporadic Medullary Thyroid Carcinomas
}

\author{
Shigeto MAEDA, Hiroyuki NAMBA*, NoBoru TAKAMURA*, \\ KEN TANIGAWA*, MASAHIDE TAKAHASHI**, SHIROH NOGUCHI***,

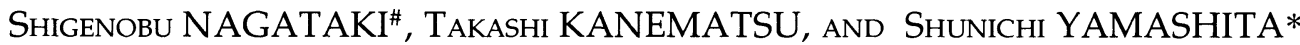 \\ Second Department of Surgery, *Department of Cell Physiology, \\ Atomic Disease Institute, Nagasaki University School of Medicine, Nagasaki 852, \\ **Department of Pathology, Nagoya University School of Medicine, Nagoya 466, \\ ***Noguchi Hospital, Ohita 874, and ${ }^{\sharp}$ First Department of Internal Medicine, \\ Nagasaki University School of Medicine, Nagasaki 852, Japan
}

\begin{abstract}
The RET proto-oncogene is expressed in human medullary thyroid carcinoma and pheochromocytoma. Recently germline mutations of the RET proto-oncogene were reported in four syndromes (MEN 2A, MEN 2B, familial medullary thyroid carcinoma and Hirschprung's disease) and somatic mutation was also found in sporadic medullary thyroid carcinoma. To determine the incidence of $R E T$ mutations in medullary thyroid carcinoma in Japan, we investigated 14 medullary thyroid carcinomas (comprising 1 case of MEN 2A, 1 case of MEN 2B, 2 cases of familial medullary thyroid carcinoma and 10 cases of sporadic). Tumors from all cases were screened by PCR-SSCP on exons 10 and 11. DNA sequencing on these exons was performed for the hereditary medullary thyroid carcinoma cases. The PCR products of exon 16 from tumor DNA were analyzed by means of Fok 1 restriction enzyme digestion analysis and mutations confirmed by DNA sequencing. We found no structural abnormalities in either exon 10 or exon 11 in any of the cases examined, but in four of 10 sporadic cases we detected a common point mutation at codon 918 (ATG to ACG) in exon 16, where methionine was replaced with threonine. Our results support the theory that a point mutation of exon 16 of the RET proto-oncogene may be related to the oncogenesis of sporadic medullary thyroid carcinomas. However, further studies on the entire RET proto-oncogene are needed to clarify the relationship between its expression and thyroid tumorigenesis.
\end{abstract}

Key words: RET proto-oncogene, Medullary thyroid carcinoma, Point mutation

(Endocrine Journal 42: 245-250, 1995)

MEDULLARY thyroid carcinoma (MTC) arises from the $C$ cells, which embryologically emerge from the neural crest, and have the ability to synthesize and secrete calcitonin and other peptides [1]. MTC may occur as either sporadic or heredi-

Received: July 11, 1994

Accepted: December 7, 1994

Correspondence to: Dr. Shunichi YAMASHITA, Department of Cell Physiology, Atomic Disease Institute, Nagasaki University School of Medicine, 1-12-4 Sakamoto, Nagasaki 852, Japan tary tumors, the latter constituting a dominantly inherited syndrome characterized by bilateral, often multifocal thyroid tumors and diffuse C-cell hyperplasia throughout the thyroid gland, and is accompanied to varying degrees by hyperplasia or tumor formation in the adrenal medulla and parathyroid glands. The autosomal dominant syndromes with MTC are classified into three types: multiple endocrine neoplasia type 2A (MEN 2A), MEN 2B and familial MTC (FMTC) [2]. MEN 2A is characterized by predisposition to adrenal pheo- 
chromocytomas and to parathyroid hyperplasia. MEN 2B is the most severe form of the MEN 2 syndrome and is associated with MTC, pheochromocytoma in $90 \%$ of cases, mucosal neuromas, ganglioneuromas of the intestinal tract, and skeletal and ophthalmic abnormalities. FMTC is characterized by an inherited predisposition to MTC without evidence of pheochromocytoma or parathyroid disease. The sporadic form has been found in about $20 \%$ of the total MTC. The causes of these phenotypic differences are still unknown. The locus of the defective gene for these syndromes was localized in a region on chromosome $10 \mathrm{q} 11.2$ by means of genetic linkage analysis [3, 4]. Recently, the germ-line missense mutations of the RET proto-oncogene were identified in MTC associated with MEN 2A, 2B and FMTC [5-10]. These mutations were restricted to the extracellular cysteine rich domain (exon 10 and 11) and intracellular tyrosine kinase catalytic domain (exon 16). To investigate the genetic basis for MTC, we analyzed the exons 10, 11 and 16 of the RET proto-oncogene for mutations in sporadic and familial MTC.

\section{Materials and Methods}

\section{Materials}

Human medullary thyroid carcinoma tissues were obtained from surgical specimens at the Nagasaki University Hospital, Noguchi Hospital, Yamaguchi Prefectural Hospital and Ishigaki Clinic. Fourteen medullary thyroid cancers (MEN 2A 1 case MEN 2B 1 case, familial medullary thyroid carcinoma 2 cases and sporadic medullary thyroid carcinoma 10 cases) were investigated. These tissues were fixed with formalin and embedded in paraffin blocks. Fifty- $\mu$ m-thick sections from each block were deparaffinized $(1 \mathrm{ml}$ of xylene twice, followed by $100 \%$ ethanol twice) and used for DNA extraction. Deparaffinized samples were treated in $100 \mu l$ of digestion buffer $(50 \mathrm{mM}$ Tris- $\mathrm{HCl}, \mathrm{pH}$ $8.5,1 \mathrm{mM}$ EDTA, $0.5 \%$ Tween 20) with $100 \mu \mathrm{g}$ of proteinase $\mathrm{K}$ at $37{ }^{\circ} \mathrm{C}$ for $48 \mathrm{~h}$. After phenol-chloroform extraction, genomic DNA was precipitated with ethanol.

\section{Oligonucleotide primers and PCR}

The sequence of RET intronic and exonic prim- ers blanketing exons 10, 11 and 16 were synthesized according to published reports $[5,7,11]$ and information from Dr. M. Takahashi (Nagoya University, School of Medicine).

Oligonucleotide primer sequences in exons 10, 11 and 16 are as follows ;

fRET 10 5'-GCGCCCCAGGAGGCTGAGTG-3' rRET 10 5'-CGTGGTGGTCCCGGCCGCC-3'.

fRET 11 5'-GGTGCCAAGCCTCACACCAC-3' rRET 11 5'-ATCTTGAAGGCATCCACGGA-3' fRET 16 5'-AGGGATAGGGCCTGGGCTTC-3' rRET 16 5'-TAACCTCCACCCCAAGAGAG-3' PCR was performed with 100 ng genomic DNA, $20 \mathrm{pmol}$ of each primer, $200 \mu \mathrm{M}$ dNTPs $10 \mathrm{mM}$ $\mathrm{KCl}, 10 \mathrm{mM}$ Tris- $\mathrm{HCl}$ (pH 8.8), $1.5 \mathrm{mM} \mathrm{MgCl} 2,1 \%$ TritonX-100, and 1.25 units of Taq DNA polymerase, in a final volume of $50 \mu l$. The PCR (35 cycles) was carried out in a Thermal Cycler under the following conditions;

for exon 10: $30 \mathrm{sec}$ at $94{ }^{\circ} \mathrm{C}$ (denaturation); $30 \mathrm{sec}$ at $68{ }^{\circ} \mathrm{C}$ (annealing); and $1 \mathrm{~min}$ at $72{ }^{\circ} \mathrm{C}$ (polymerization)

for exon 11: $1 \mathrm{~min}$ at $94{ }^{\circ} \mathrm{C}$ (denaturation), $30 \mathrm{sec}$ at $55{ }^{\circ} \mathrm{C}$ (annealing); and $30 \mathrm{sec}$ at $72{ }^{\circ} \mathrm{C}$ (polymerization)

for exon 16: $35 \mathrm{sec}$ at $94^{\circ} \mathrm{C}$ respectively (denaturation), $35 \mathrm{sec}$ at $58{ }^{\circ} \mathrm{C}$ (annealing); and $35 \mathrm{sec}$ at 72 ${ }^{\circ} \mathrm{C}$ (polymerization). Predicted DNA sizes were $185 \mathrm{bp}, 272 \mathrm{bp}$ and $192 \mathrm{bp}$, respectively.

\section{Single-Strand Conformation Polymorphism (SSCP) analysis}

In an effort to evaluate RET proto-oncogene as a candidate for medullary thyroid carcinoma, we applied single strand conformation polymorphism (SSCP) analysis of constitutional and tumor DNA, screening amplified products of exon 10 and 11. Formamide dye (88\% formamide, $10 \mathrm{mM}$ EDTA, $0.01 \%$ bromophenol blue, $\mathrm{pH} 8.0$ ) was added to an aliquot $(0.1-0.2 \mu \mathrm{g})$ of PCR product to obtain a final concentration of $50 \%$ formamide. Samples were incubated at $96{ }^{\circ} \mathrm{C}$ for $5 \mathrm{~min}$, and rapidly chilled on ice. The samples were electrophoresed in an $8 \%$ polyacrylamide gel $(0.4 \times \mathrm{TBE})$ in $0.5 \times$ TBE. Electrophoresis was performed 4 times for each product by changing the temperature and the concentration of the glycerol. DNA fragments were detected with a silver staining kit (Daiichi Chemical Co., Ltd., Tokyo) according to the manufacturer's instructions [12]. 


\section{Restriction enzyme digestion}

PCR products $(0.5 \mu \mathrm{g}$ of each) of exon 16 were digested with 10 units of Fok 1 at $37^{\circ} \mathrm{C}$ for $16 \mathrm{~h}$ (according to the manufacturers' recommendations) and fractionated by electrophoresis on the $10 \%$ polyacrylamide gel. Gels were stained with 0.5 $\mu \mathrm{g} / \mathrm{ml}$ ethidium bromide for $30 \mathrm{~min}$.

\section{DNA sequencing}

Amplified PCR products were purified on 1\% agarose gels by QIAX kit (QIAGEN Inc. Chatsworth, USA). Sequencing was performed with dsDNA Cycle Sequencing System (GIBCO BRL, Gaithersburg, USA) or a 373A DNA Sequencing System (Applied Biosystem Japan, Tokyo, Japan). For direct sequencing, primers were end-labeled with $1 \mu l$ of $1 \mu \mathrm{M}$ primer, $1 \mu l$ of $5 \times$ polynucleotide kinase buffer, $1 \mu l$ of $\gamma$-32P-ATP and $1 \mu l$ of $\mathrm{T}_{4}$-PNKase. The reaction mixture was incubated at $37^{\circ} \mathrm{C}$ for $40 \mathrm{~min}$, and then heated at $65^{\circ} \mathrm{C}$ for 20 min. PCR reactions were carried out under the same conditions as for the first PCR reaction. Autoradiography was performed on Kodak X-OMAT films at $-70{ }^{\circ} \mathrm{C}$ for $1-7$ days. For the sequencing, purified PCR products were ligated to the $\mathrm{PCR}^{\mathrm{TM}}$ II vector (TA cloning Kit; Invitrogen San Diego, USA) and chimeric vectors were transformed with competent $E$. coli cells. After small scale preparation of plasmid DNA, the products were purified by QIAGEN plasmid Kit (QIAGEN Inc.) and subjected to a fluorescence-based dye primer sequence reaction with a PRISM ${ }^{\mathrm{TM}}$ Ready Reaction Dye Primer Cycle Sequencing Kit (Applied Biosystem Japan, Tokyo, Japan) for analysis with a 373A DNA Sequencer.

\section{Results}

\section{PCR-SSCP}

In order to assess the presence of the structural change in the RET proto-oncogene in medullary thyroid carcinomas, we first performed PCR-SSCP analysis on exon 10 and exon 11 of the gene. Of 14 separate medullary thyroid carcinomas screened, we found no mobility shifts for exon 10 or 11 (data not shown).
Mutation analysis of RET exon 16 by means of Fok 1 digestion

Based on previous reports [7, 9], which disclosed that a mutation in exon 16 at codon 918 (ATG to ACG) resulted in the loss of a Fok 1 restriction site [GGATG(N)9/13], we analyzed the PCR products of exon 16 with this restriction enzyme (Fig. 1). Of 14 MTC patients, we detected the undigestion pattern in four cases (sporadic MTC 4 cases). No abnormal digestion was found in 5 amplified samples when using peripheral lymphocyte DNA of normal subjects.

\section{DNA sequence}

We performed direct sequence of RET exons 10 and 11 for hereditary medullary thyroid carcinoma (MEN 2A, MEN 2B, familial medullary thyroid carcinoma 2 cases). There was no evidence for any point mutations in either exon 10 or exon 11 . To confirm the mutation in exon 16 in the four cases with sporadic MTC with the undigested Fok 1 restriction, we further examined the DNA sequence. Four of 10 sporadic MTCs had a common point mutation at the codon 918 from ATG to ACG mutation (Table 1). Table 2 shows the tumor size, serum calcitonin and CEA level of each patient examined.

\section{Discussion}

We have shown a specific mutation in the tyrosine kinase domain of the RET proto-oncogene in tumor DNA from 4 of $10(40 \%)$ sporadic MTC. The RET proto-oncogene encodes a protein that is structurally related to the tyrosine kinase transmembrane receptors $[13,14]$. Although the ligand is still unknown, the physiological expression of RET proto-oncogene is restricted to cells of neuroendocrine origin [15-17]. In cell lines of this type, such as medullary thyroid carcinoma or neuroblastoma cells, retinoic acid-induced differentiation is accompanied by enhancement in RET expression, suggesting a role in the transduction of differentiational signals [18].

Previous reports revealed point mutations in the extracellular domain of the RET proto-oncogene in germ line DNA from MEN 2A and FMTC $[5,6,8]$ 


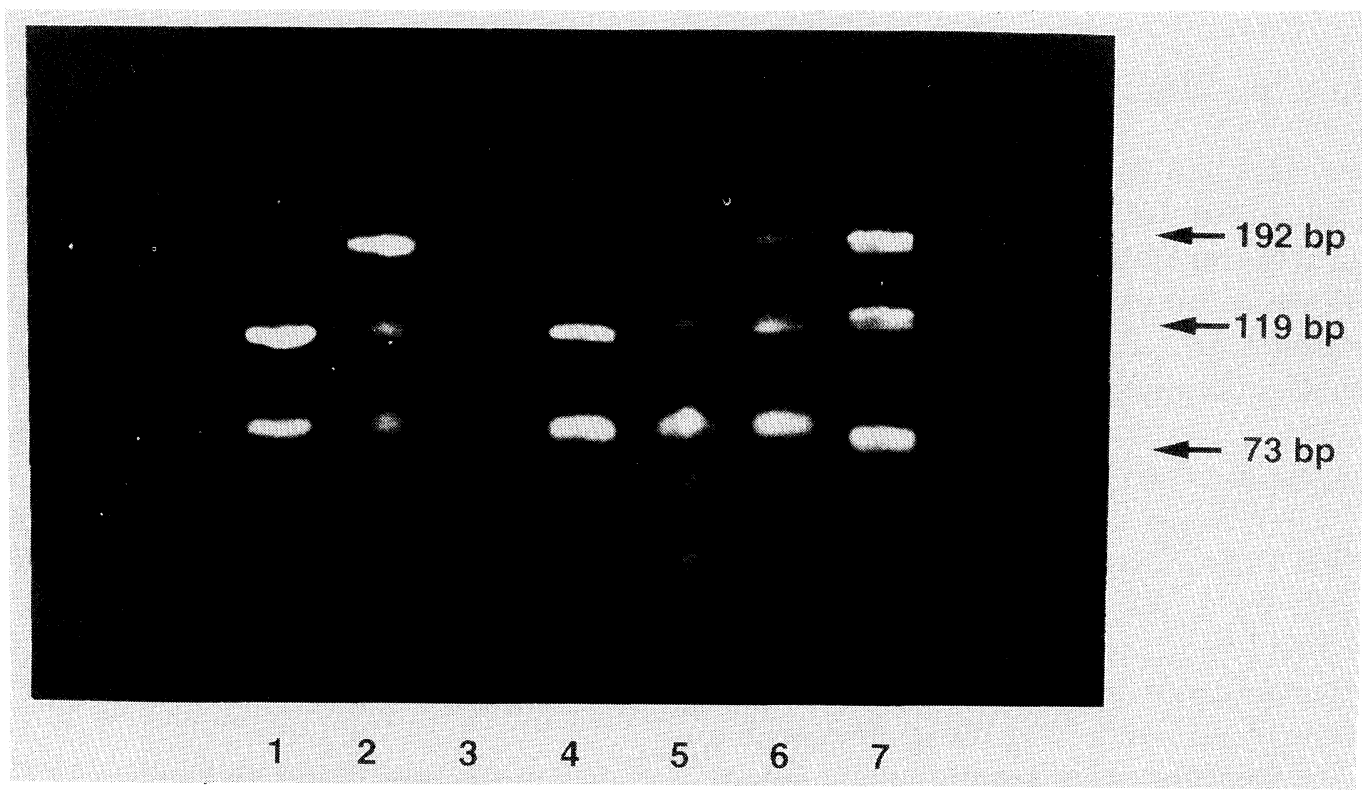

Fig. 1. Restriction patterns of PCR products of exon 16 with Fok1. PCR products of RET exon 16 were isolated and purified as described in Materials and Methods. After digestion with $10 \mathrm{U}$ Fok1 for $16 \mathrm{~h}$, the samples were electrophoresed on a $10 \%$ polyacrylamide gel and stained with ethidium bromide. Although the normal allele at codon 918 has a Fok1 restricted site, the mutated allele is not restricted. The predicted band sizes are $192 \mathrm{bp}$ at undigestion and 119 and $73 \mathrm{bp}$ at digestion. Lane 1, normal lymphocyte DNA ; Lanes 2-7, tumor DNAs from sporadic MTC. Samples in lanes 2 and 7 have mutated patterns.

Table 1. Ret mutation in medullary thyroid carcinomas

\begin{tabular}{lcccc}
\hline Group & Total no. & \multicolumn{3}{c}{ Number of mutation in $R E T$ gene } \\
\cline { 3 - 5 } & & exon 10 & exon 11 & exon 16 \\
\hline Control & 5 & 0 & 0 & 0 \\
MEN2A & 1 & 0 & 0 & 0 \\
MEN2B & 1 & 0 & 0 & 0 \\
Familial & 2 & 0 & 0 & 0 \\
Sporadic & 10 & 0 & 0 & 4 \\
\hline
\end{tabular}

and in the tyrosine kinase domain from MEN 2B and sporadic MTC $[7,9,10]$. The RET extracellular domain contains a ligand binding region characterized by highly conserved cysteine residues in RET exons 10 and 11. All of the mutations identified in cases of MEN 2A and FMTC are restricted to these cysteine rich regions and result in nonconservative substitutions for four different cysteines. Mulligan et al. [8] reported the mutations in this region were found in $97 \%$ of patients with MEN 2A and 86\% with FMTC but not in MEN 2B patients. The most frequent mutation in MEN 2A

Table 2. Cases with sporadic medullary thyroid carcinoma

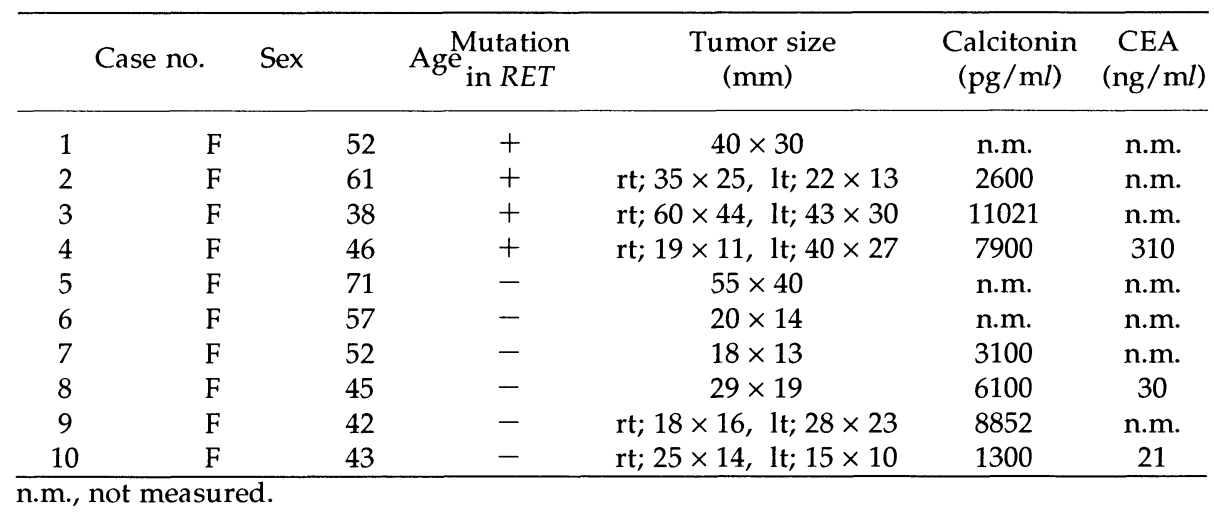


was observed at codon 635 representing $84 \%$ of cases examined. In the cases which we examined (MEN 2A 1 case and FMTC 2 cases), no mutations was found in exon 10 or 11 . As our MEN 2A case has unique clinical features characteristic of malignant pheochromocytoma that metastasized to the lungs and liver, de novo mutation site(s) might exist in other exon(s) of the RET gene or in other oncogenes. As only a small number of hereditary MTCs were examined in this study, a large scale study will help to find mutation sites in the RET gene in the hereditary MTCs in Japan.

The MEN 2B and sporadic MTCs examined to date all show the same heterozygous missense change at codon 918 (exon 16) in the RET tyrosine kinase domain $[7,9,10]$. The frequency of this mutation was approximately $60-100 \%$ in MEN 2B and $30-40 \%$ in sporadic MTC. The mutation (ATG $\rightarrow \mathrm{ACG}$ ) results in the replacement of methionine with threonine within the catalytic core region of the tyrosine kinase domain. Although we identified the missense mutation of the RET codon 918 in tumor cells of four sporadic MTC, no relationship was found between this mutation and clinical features. Further screening study may define the difference in the disease among tumors with and without the mutation. A previous report showed the mutations of the RET proto-oncogene are also associated with non-neuroendocrine tumors. Rearranged forms of $R E T$ were isolated from a human T-cell lymphoma [19] and subsequently from human colon DNA, by means of transfection onto NIH 3T3 fibroblasts $[20,21]$ and thyroid papillary carcinoma in vivo [22]. In each of these cases, RET oncogenes arose through recombination events of the $R E T$ proto-oncogene with the $5^{\prime}$-terminal sequences of different genes [20-22]. A study with a chimeric expression vector, which encoded a mol- ecule encompassing the extracellular domain of the epidermal growth factor receptor (EGFR) and the intracellular domain of the RET kinase, suggested that the RET kinase signal is transmitted through a raf-MAPK independent pathway [23]. These data suggest that activation of tyrosine kinase by $R E T$ rearrangement has a transforming activity in nonneuroendocrine cells. But it is not clear whether the point mutations of the RET proto-oncogene which exist in MTC continuously stimulate the activity of tyrosine kinase or diminish the signal transduction from the ligand in neuroendocrine cells. It is necessary to know the ligand and how functional alterations occur in cells due to missense mutations in the signal transduction system. Studies on transgenic mice carrying these mutations will be useful in elucidating how disease phenotypes are conferred by each mutation of the RET proto-oncogene.

To detect the mutation of codon 918 in RET proto-oncogene might be useful in assisting the early or definite diagnosis of MTC. Furthermore, ultimately these syndromes would be good targets for gene therapy.

\section{Acknowledgment}

We thank Dr. H. Hongou (Yamaguchi Prefectural Hospital) and Dr. J. Ishigaki (Ishigaki Clinic) for providing surgical specimens. We are grateful to Mr. Adachi and Ms. S. Fukuda for technical assistance. We also thank Ms. C. Ichinose and Y. Tsunoo for excellent secretarial assistance. This work was supported by a grant-in-aid from the Ministry of Education, Culture and Science of Japan (to H.N no. 06671039 and S.Y no. 06454340 ).

\section{References}

1. Hazard JB (1977) The C-cells (parafollicular cells) of the thyroid gland and medullary thyroid carcinoma: A review. Am J Pathol 88: 214-249.

2. Schimke RN (1984) Genetic aspects of multiple endocrine neoplasia. Ann Rev Med 35: 25-31 .

3. Mole SE, Mulligan LM, Healey CS, Ponder BAJ, Tunnacliffe A (1993) Localization of the gene for multiple endocrine neoplasia type $2 \mathrm{~A}$ to a $480 \mathrm{~kb}$ region in chromosome band 10q11.2. Hum Mol Genet
2: 247-252.

4. Lairmore TC, Dou S, Howe JR, Chi D, Carlson K, Veile R, Mishra SK, Wells SA Jr, Donis-Keller H (1993) A 1.5-megabase yeast artificial chromosome contig from human chromosome 10q11.2 connecting three genetic loci (RET, D10S94 and D10S102) closely linked to the MEN2A locus. Proc Natl Acad Sci USA 90: 492-496.

5. Donis-Keller H, Dou S, Chi D, Toshima K, Lairmore 
TC, Howe JR, Moley JF, Goodfellow P, Wells SA (1993) Mutations in the RET proto-oncogene are associated with MEN 2A and FMTC. Hum Mol Genet 2: 851-856.

6. Mulligan LM, Kwok JBJ, Healey C S, Elsdon MJ, Eng C, Gardner E, Love DR, Mole SE, Moore JK, Papi L, Ponder MA, Telenius H, Tunnacliffe A, Ponder BAJ (1993) Germ-line mutations of the RET proto-oncogene in multiple endocrine neoplasia type 2A. Nature 363: 458-460.

7. Hofstra R, Landsvater RM, Ceccherini I, Stulp RP, Stelwagen T, Luo Y, Pasini B, Hoppener JWM, Van Amstel HKP, Romeo G, Lips CJM, Buys CHC (1994) A mutation in the RET proto-oncogene associated with multiple endocrine neoplasia type $2 \mathrm{~B}$ and sporadic medullary thyroid carcinoma. Nature 367 : 375-376.

8. Mulligan LM, Eng C, Healey CS, Clayton D, Kwok JBJ, Gardner E, Ponder MA, Frilling A, Jackson CE, Lehnert H, Neumann HPH, Thibodeau SN, Ponder BAJ (1994) Specific mutations of the RET protooncogene are related to disease phenotype in MEN2A and FMTC. Nature Genetics 6: 70-74.

9. Carlson KM, Dou S, Chi D, Scavarda N, Toshima $\mathrm{K}$, Jackson CE, Wells SA Jr, Goodfellow PJ, DonisKeller H (1994) Single missense mutation in the tyrosine kinase catalytic domain of the RET protooncogene is associated with multiple endocrine neoplasia type 2B. Proc Natl Acad Sci USA 91: 15791583.

10. Eng C, Smith DP, Mulligan LM, Nagai MA, Healey CS, Ponder MA, Gardner E, Scheumann GFW, Jackson CE, Tunnacliffe A, Ponder BAJ (1994) Point mutation within the tyrosine kinase domain of the $R E T$ proto-oncogene in multiple endocrine neoplasia type $2 \mathrm{~B}$ and related sporadic tumors. Hum mol Genet 3: 237-241

11. Ceccherini I, Bocciardi $R$, Luo $Y$, Pasini B, Hofstra R, Takahashi M, Romeo G (1993) Exon structure and flanking intoronic sequences of the human ret proto-oncogene. Biochem Biophys Res Commun 196: 1288-1295.

12. Hoshino S, Kimura A, Fukuda Y, Dohi K, Sasazuki $T$ (1992) Polymerase chain reaction-single-strand conformation polymorphism analysis of polymorphism in DPA1 and DPB1 genes: a simple, economical, and rapid method for histocompatibility testing. Human immunology 33: 98-107.

13. Takahashi $M$, Buma $Y$, Iwamoto $T$, Inaguma $Y$, Ikeda H, Hiai H (1988) Cloning and expression of the ret proto-oncogene encoding a tyrosine kinase with two potential transmembrane domains. Oncogene 3: 571-578.

14. Takahashi M, Cooper GM (1987) RET transforming gene encodes a fusion protein homologous to tyrosine kinases. Mol Cell Biol 7: 1378-1385.

15. Ikeda I, Ishizaka Y, Tahira T, Suzuki T, Onda M, Sugimura T, Nagao M (1990) Specific expression of the ret proto-oncogene in human neuroblastoma cell lines. Oncogene 5: 1291-1296.

16. Miya A, Yamamoto M, Morimoto $H$, Tanaka N, Shin E, Karakawa K, Toyoshima K, Ishizaka Y, Mori T, Takai S (1992) Expression of the ret protooncogene in human medullary thyroid carcinomas and pheochromocytomas of MEN 2A. Henry Ford Hosp Med J 40: 215-219.

17. Santoro $M$, Rosato $R$, Grieco $M$, Berlingieri MT, Colucci D'Amato GL, de Franciscis V, Fusco A (1990) The ret proto-oncogene is consistently expressed in human pheochromocytomas and thyroid medullary carcinomas. Oncogene 5: 1595-1598.

18. Tahira $T$, Ishizaka $Y$, Itoh $F$, Nakayasu $M$, Sugimura T, Nagao M (1991) Expression of the ret protooncogene in human neuroblastoma cell lines and its increase during neuronal differentiation induced by retinoic acid. Oncogene 6: 2333-2338.

19. Takahashi M, Ritg J, Cooper GM (1985) Activation of a novel human transforming gene, ret, by DNA rearrangement. Cell 42: 581-588.

20. Ishizaka $Y$, Ochiai $M$, Tahira $T$, Sugimura $T$, Nagao $M$ (1989) Activation of the retII oncogene without sequence encoding a transmembrane domain and transforming activity of two retII oncogene products differing in carboxytermini due to alternative splicing. Oncogene 4: 789-794.

21. Ishizaka $Y$, Tahira T, Ochiai M, Ikeda I, Sugimura T, Nagao M (1988) Molecular cloning and characterization of human retII oncogene. Oncogene Res 3: 193-197.

22. Grieco M, Santoro M, Berlingieri T, Melillo RM, Donghi R, Bongarzone I, Pierotti MA, Della Porta G, Fusco A, Vecchio G (1990) PTC is a novel rearranged form of the ret proto-oncogene and is frequently detected in vivo in human thyroid papillary carcinomas. Cell 60: 557-563.

23. Edery P, Lyonnet S, Mulligan LM, Pelet A, Dow E, Abel L, Holder S, Nihoul-Fekete C, Ponder BAJ, Munnich A (1994) Mutations of the RET protooncogene in Hirchsprung's disease. Nature 367: 378-380. 